\title{
The Role of Synapsins in Neurological Disorders
}

\author{
Fatima Javed Mirza ${ }^{1} \cdot$ Saadia Zahid ${ }^{1}$
}

Received: 14 March 2017/ Accepted: 27 October 2017/Published online: 27 December 2017

(C) Shanghai Institutes for Biological Sciences, CAS and Springer Nature Singapore Pte Ltd. 2017

\begin{abstract}
Synapsins serve as flagships among the presynaptic proteins due to their abundance on synaptic vesicles and contribution to synaptic communication. Several studies have emphasized the importance of this multi-gene family of neuron-specific phosphoproteins in maintaining brain physiology. In the recent times, increasing evidence has established the relevance of alterations in synapsins as a major determinant in many neurological disorders. Here, we give a comprehensive description of the diverse roles of the synapsin family and the underlying molecular mechanisms that contribute to several neurological disorders. These physiologically important roles of synapsins associated with neurological disorders are just beginning to be understood. A detailed understanding of the diversified expression of synapsins may serve to strategize novel therapeutic approaches for these debilitating neurological disorders.
\end{abstract}

Keywords Synapsin I · Synapsin II · Synapsin III · Neurological disorders

\section{Introduction}

Neuronal transmission has always been considered a crucial subject for research, as all life activities of human beings depend on it. Among the numerous proteins

Saadia Zahid

saadiazahid@hotmail.com; saadia.zahid@asab.nust.edu.pk

1 Neurobiology Research Laboratory, Department of Healthcare Biotechnology, Atta-ur-Rahman School of Applied Biosciences, National University of Sciences and Technology, Islamabad, Pakistan localized within the presynaptic terminals, synapsins serve as the flagships. They were the first presynaptic proteins to be identified and are also the most abundant on synaptic vesicles [1]. As the synapsins are involved in synaptogenesis and neuronal plasticity [2, 3], their alteration may result in neurological disorders like Alzheimer's disease (AD), epilepsy, schizophrenia, multiple sclerosis (MS), and autism spectrum disorder (ASD) [4]. In this review, we systematically discuss the involvement and possible roles of synapsins in various neurological disorders.

\section{Synapsin Proteins and Subtypes}

Synapsins belong to a class of neuron-specific phosphoproteins and comprise $\sim 1 \%$ of the total brain proteins, making them one of the most abundant families of synaptic proteins [5]. They have been recognized to be significantly involved in synaptogenesis and neuronal plasticity, including the regulation of synapse development, modulation of neurotransmitter release, and formation of nerve terminals [6-8] (Fig. 1). They act mainly by associating with the synaptic vesicle membrane at the cytoplasmic surface [9]. The binding of synapsins to synaptic vesicles is governed by their phosphorylation state. In the dephosphorylated state, they bind synaptic vesicles, while on phosphorylation they dissociate from the vesicles and mobilize, allowing for eventual exocytosis [10]. In vertebrates, three distinct genes termed Synapsin I, II, and III code for these proteins, while alternative splicing of each of these genes generates distinct isoforms [11-13]. 


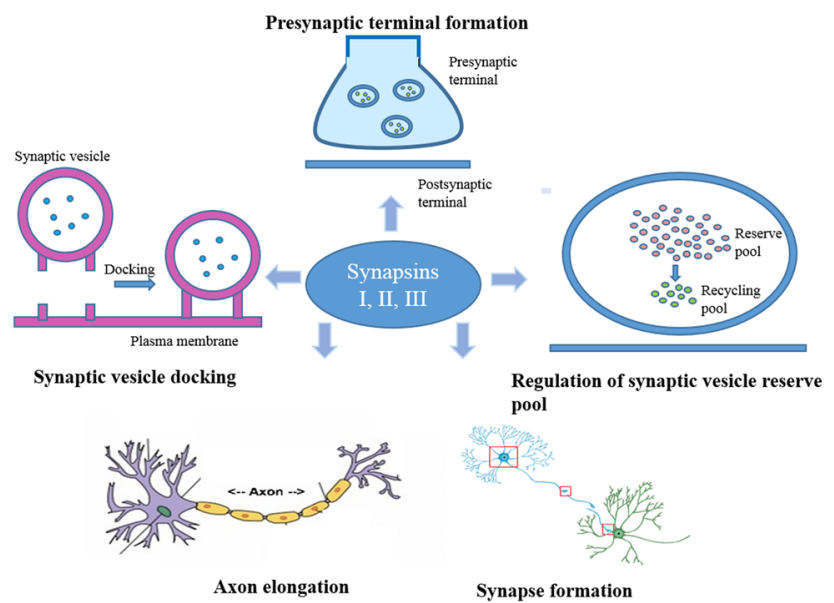

Fig. 1 The major functions of synapsins. These neuron-specific phosphoproteins are active in various regulatory functions at the synapses which include the formation of presynaptic terminals, regulation of the vesicle reserve pool at presynaptic terminals, synaptogenesis, elongation of axons, and synaptic vesicle docking.

\section{Synapsin I}

Synapsins are abundant in most nerve cells; however, the different neuronal types have differential distribution of its isoforms [11], with synapsins I and II being the major isoforms in neurons [14]. Synapsin I is associated with elongation of the axon and regulation of the kinetics of synaptic vesicle fusion [15, 16] (Fig. 2). Both isoforms of synapsin I ( Ia and Ib) play important roles in synapse formation where they specifically minimize depletion of the neurotransmitter at the inhibitory synapses by contributing to the anchoring of synaptic vesicles $[17,18]$. It also regulates synaptogenesis and modulates

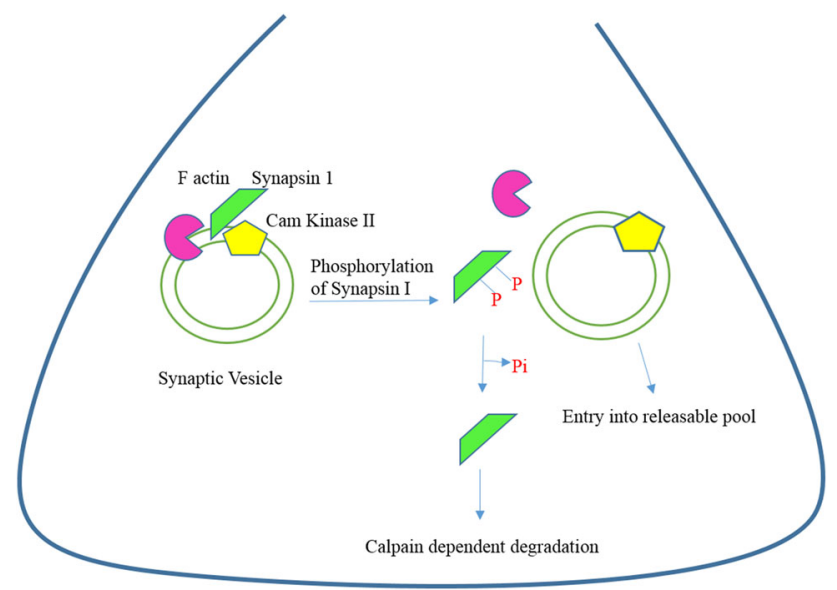

Fig. 2 Synapsin I and synaptic vesicle trafficking. The binding of synapsins to synaptic vesicles is governed by their phosphorylation state. In the dephosphorylated state, they bind synaptic vesicles, while on phosphorylation they dissociate from the vesicles and mobilize, allowing for eventual exocytosis. Phosphorylation of synapsin I plays an important role in mediating the trafficking of synaptic vesicles. neurotransmitter release as demonstrated by a study on synapsin I-deficient mice. These mice, generated by homologous recombination, revealed altered synaptic vesicle organization at presynaptic terminals in addition to a reduction in neurotransmitter release and delayed recovery of synaptic transmission after neurotransmitter depletion [19].

\section{Synapsin II}

Although synapsin II plays roles in cellular processes similar to those in which synapsin I is involved, many studies have also demonstrated its distinct functions. Knockdown of synapsin II in hippocampal neurons results in deficient axon elongation [20] and disrupted synapse formation [21], indicating its substantial role in synaptogenesis. In addition, synapsin II is considered to be a crucial component of the synaptic vesicle cycle through its involvement in vesicle docking [22]. The synapsin IIa isoform regulates the vesicular reserve pool at glutamatergic synapses [23], while synapsin IIb is involved in the formation of presynaptic terminals [24].

\section{Synapsin III}

Synapsin III is developmentally controlled and predominantly expressed in the early phase of neuronal development; however its role in the regulation of synaptogenesis, neurogenesis, and neuronal plasticity is attributable to active process elongation and changes in axonal differentiation $[25,26]$. The regulation of neurotransmitter release by synapsin III proceeds in a manner entirely different from the other isoforms. For instance, knockout (KO) of synapsin III causes a decrease in synaptic depression and an increase in the size of the synaptic vesicle pool, the latter of which is opposite to that in synapsin I- and II-KO animals. Similarly, mice lacking synapsin III do not show abnormal neurotransmitter release at excitatory synapses but only at inhibitory synapses [27]. Moreover, the localization of synapsin III differs, being abundant at extrasynaptic sites and in the growth cones of hippocampal neurons, unlike synapsin I and II which are found mainly at presynaptic nerve terminals [25]. The involvement of synapsins in various cellular processes is summarized in Table 1.

\section{Association of Synapsins with Neurological Disorders}

Synapsin genes have been associated with several neurological disorders such as schizophrenia, bipolar disorder (BD), AD, MS, Huntington's disease (HD), and epilepsy, 
Table 1 Synapsin functions, localization, and associated pathological conditions.

\begin{tabular}{|c|c|c|c|c|c|}
\hline Protein & $\begin{array}{l}\text { Accession } \\
\text { no. }\end{array}$ & Functions & Cellular localization & Mutations and SNPs & $\begin{array}{l}\text { Associated patho- } \\
\text { logical conditions }\end{array}$ \\
\hline $\begin{array}{l}\text { Synapsin } \\
\text { I }\end{array}$ & P17600 & $\begin{array}{l}\text { Chemical synaptic transmission, neurotrans- } \\
\text { mitter secretion, regulation of neurotrans- } \\
\text { mitter secretion and synaptic vesicle } \\
\text { exocytosis, synaptic vesicle clustering }\end{array}$ & Synapse & $\begin{array}{l}\text { Q555X [52], A548T } \\
\text { [90] }\end{array}$ & $\begin{array}{l}\text { AD, Epilepsy, BD, } \\
\text { MS, Huntington's } \\
\text { disease, ALS, } \\
\text { ASD }\end{array}$ \\
\hline $\begin{array}{l}\text { Synapsin } \\
\text { II }\end{array}$ & Q92777 & $\begin{array}{l}\text { Chemical synaptic transmission, neurotrans- } \\
\text { mitter secretion }\end{array}$ & $\begin{array}{l}\text { Synapse, Synaptic } \\
\text { vesicle membrane }\end{array}$ & $\begin{array}{r}(\mathrm{rs} 37733634) \\
\quad \mathrm{A}>\mathrm{G}[53]\end{array}$ & $\begin{array}{l}\text { AD, Epilepsy, } \\
\text { Schizophrenia, } \\
\text { BD, MS, ALS, } \\
\text { Hyperalgesia }\end{array}$ \\
\hline $\begin{array}{l}\text { Synapsin } \\
\text { III }\end{array}$ & O14994 & $\begin{array}{l}\text { Neurotransmitter secretion, regulation of } \\
\text { synaptic transmission }\end{array}$ & $\begin{array}{l}\text { Cell junction, Cyto- } \\
\text { plasmic vesicle, } \\
\text { synaptic vesicle and } \\
\text { its membrane }\end{array}$ & $\begin{array}{l}-196 \mathrm{G}>\mathrm{A}[70] \\
-631 \mathrm{C}>\mathrm{G} \\
-69 \mathrm{G}>\mathrm{A} \\
{[73,81], \text { Ser470N }} \\
{[69]}\end{array}$ & $\begin{array}{l}\text { AD, Schizophrenia } \\
\text { BD, MS }\end{array}$ \\
\hline
\end{tabular}

Accession no. and functional categories obtained by UniProtKB.

as demonstrated by both genetic and functional studies. These studies provide satisfactory evidence that a difference in the expression of synapsin genes/proteins is associated with neurological phenotypes and lead to further interest in understanding the potential regulatory mechanisms that underlie these changes.

The present paper systematically reviews the potential derangements in synapsin I, II, and III expression and polymorphisms/mutations that contribute to the pathological consequences associated with various neurological disorders.

\section{Alzheimer's Disease}

$\mathrm{AD}$, the most common form of dementia accounting for more than $80 \%$ of the cases reported worldwide [28], is characterized by the progressive loss of cortical neurons that are involved in the mediation of higher cognitive functions [29]. The major clinical manifestations are loss of memory, cognitive dysfunction, and learning deficits $[30,31]$.

Synaptic loss [32] and neurofibrillary pathology [33] in the limbic system and neocortex are involved in the cognitive alterations in AD patients. Synaptic loss in the dentate gyrus of the hippocampus is predominant in the early phase of development of AD [34]. Regional alterations in synapsin I occur in the hippocampal formation, reported as a significant decrease in the immunoreactivity of synapsin I in the stratum radiatum of the CA1 subfield of the hippocampus and the molecular layer of the dentate gyrus in $\mathrm{AD}$ patients [35].

A significant decrease in the level of the synapseassociated proteins glutamate receptor 2, postsynaptic density protein (PSD) 95, and synapsin I after the induction of endoplasmic reticulum (ER) stress provides further insight into cognitive deficits and defective neurotransmission in the hippocampus in $\mathrm{AD}$ [36]. Moreover, a significant loss of the presynaptic markers synapsin- 1 and synaptophysin and the postsynaptic markers PSD-95 and synapse-associated protein 97 in individuals with mild cognitive impairment, also indicates the association of posterior cingulate gyrus synaptic function with significant synaptic loss in the prodromal and advanced stages of $\mathrm{AD}$ $[37,38]$.

Interestingly, the sorting-related receptor with A-type repeats (SORLA), which is involved in the inhibition of amyloid precursor protein (APP) trafficking into cellular compartments, also reduces the extent of proteolytic breakdown of APP into neurotoxic amyloid- $\beta$ (A $\beta$ ) peptide. It interacts strongly with phospho-synapsins I and II and subsequently promotes their degradation by the protease calpain. However, a loss of synapsin-SORLA interaction results in the accumulation of phosphorylated synapsins in the cortex and hippocampus, thereby contributing to synaptic dysfunction in AD [39].

Another interesting notion of the involvement of synapsins in $A D$ was revealed by a study of mutations in presenilin-1 (PS-1), which is one of the major players in AD pathogenesis. Mutations in exon 9 of the PS- 1 gene manifest space-occupying "cotton-wool" plaques (CWPs) lacking dense $A \beta$ cores. The increased synapsin I and synaptophysin immunoreactivity evident in CWPs suggests their potential involvement in synaptic structure and protein expression [40].

Several studies have proposed various treatment strategies targeting the restoration of synaptic proteins levels. In this context Osthole, a natural coumarin derivative isolated from Cnidium monnieri (L.), has emerged as a promising therapeutic that exerts its neuroprotective effect by 
suppressing the reduction of synaptic proteins synapsin-1, synaptophysin, and PSD 95, resulting in increased microRNA-9 expression and a subsequent decrease in $\mathrm{Ca}^{2+} /$ calmodulin-dependent protein kinase kinase 2 and phospho-AMP-activated protein kinase alpha expression [41]. Furthermore, pramlintide, a non-aggregating analog of the hormone amylin, also improves the cognitive defects via increased hippocampal synaptic protein expression and can be used as a treatment for AD [42]. A proposed mechanistic approach is presented in Fig. 3, illustrating the potential of osthole and pramlintide.

In accordance with a rise in the number of studies suggesting interactions between synapsins and neurotrophins [43] and APP [44], as well as their association with neuronal plasticity [45], interventions focused on maintaining the expression of synapsins in the brain may be beneficial for populations at a high risk of dementia by delaying the onset of cognitive impairment [46].

\section{Epilepsy}

Epileptic seizures are one of the most commonly experienced neurological symptoms affecting almost $1 \%$ of the world population [46]. It manifests as recurring seizures associated with characteristic signs and/or symptoms of abnormal, excessive, or synchronous neuronal activity caused by persistent cerebral dysfunction [47, 48]. Many studies conducted on synapsin-KO mouse lines have demonstrated that the synapsins play a prominent role in the regulation of neuronal network excitability, and impairment in their function can result in pathological

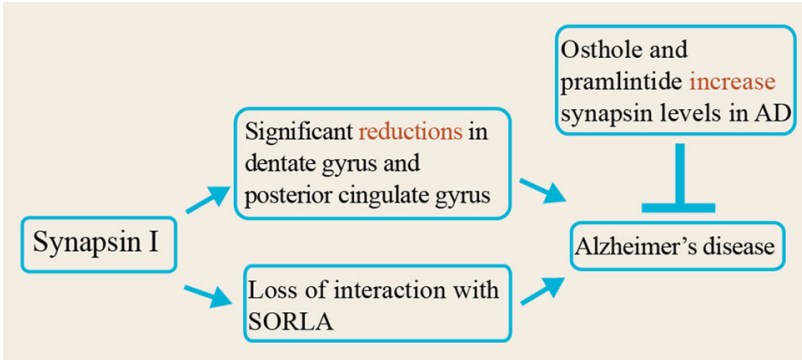

Fig. 3 Mechanisms of synapsin I involvement in AD pathogenesis and potential treatment strategies aimed at the resumption of synapsin levels. The levels of synapsin I are significantly lower in various brain regions, notably the hippocampus, dentate gyrus, and posterior cingulate gyrus, in $\mathrm{AD}$ patients. Furthermore, the sorting-related receptor with A-type repeats (SORLA), which interacts with the phosphosynapsins and causes their degradation, is inhibited in AD. This results in the accumulation of phosphorylated synapsins thereby reducing the levels of unphosphorylated synapsin I. This decrease can potentially be reversed by the use of osthole, a natural coumarin derivative isolated from the leaves of Cnidium monnieri, and pramlintide, a non-aggregating analog of the hormone amylin, thus establishing them as promising therapeutic agents against AD. conditions like epilepsy. The absence of synapsin proteins can elicit epileptic seizures brought about by a range of complex mechanisms, by affecting distinct neuronal populations in various brain areas [49].

A study conducted by $\mathrm{Li}$ et al. [19] using synapsin I-deficient mice generated by homologous recombination strongly supported the key role of synapsin I in the control of the function of the nerve terminal in mature synapses. In addition, the occurrence of nonsense and missense mutations in synapsin I in epileptic and ASD patients also asserts the notion that the pathogenesis of these diseases is associated with a disturbance of synaptic homeostasis [50]. The first mutation of this kind was reported in 2004 in a four-generation family in which some males expressed an epileptic phenotype either in isolation or in association with mental retardation and/or behavioral disturbances [51]. A more recent study was conducted by Lignani et al. in 2015 [52] to understand the involvement of synapsin I mutations in the mechanisms of epileptogenesis through an analysis of the effects of the Q555X mutation on the neurotransmitter release dynamics and short-term plasticity (STP) in excitatory and inhibitory synapses. The results revealed that the network hyperexcitability which leads to the manifestations of epilepsy/autism are triggered by imbalances in STP and the release dynamics of inhibitory and excitatory synapses.

In addition, molecular analysis has suggested that the GABRA6 T > C and Syn II A > G gene polymorphisms are significantly associated with idiopathic generalized epilepsy (IGE) in a south Indian population [53], further suggesting a role for their association with IGE in other ethnicities.

\section{Schizophrenia}

Schizophrenia is a complex, debilitating neuropsychiatric condition which is believed to be caused by various genetic and neurodevelopmental abnormalities [54]. It is characterized by auditory-verbal hallucinations due to alterations in the information flow between auditory and language processing-related regions [55]. The involvement of synapsins in the pathophysiology of schizophrenia has been determined by different studies which suggest that the pathogenesis of various neurological disorders originate from changes at synapses [56, 57]. Synapsin II and III have been implicated in schizophrenia as a decrease in their expression levels has been found in schizophrenic patients [58-60, 62]; also, single nucleotide polymorphisms (SNPs) have been associated with schizophrenia [62].

The Synapsin II gene, located on chromosome 3p25, has been suggested as a candidate gene for schizophrenia based on functional linkage and association studies. A 
significantly reduced protein content of synapsin II [59] has been reported in postmortem studies of schizophrenic brains. Also, there is a substantial decrease in the synapsin II mRNA in the dorsolateral and medial prefrontal cortex of schizophrenic patients, clearly demonstrating its role in the pathophysiology of the disease $[60,61]$.

The linkage and association of synapsin II gene polymorphisms with schizophrenia have also yielded interesting results. Studies using microsatellite markers and SNPs have revealed a possible involvement of the synapsin II gene in the etiology or pathogenesis of schizophrenia [63]. Using SNPs (rs308963 and rs795009) and two insertion/deletion polymorphisms (rs2307981 and rs2308169) in synapsin II in schizophrenic patients revealed significant differences in the allele frequency distribution between patients and control subjects, further asserting the positive association between synapsin II and schizophrenia [64]. Moreover, a family-based association study has also suggested a role of synapsin II variants in susceptibility to schizophrenia [65].

Synapsin III, located in chromosomal region 22q13 (13.1-13.31), is also considered to be a susceptibility locus for schizophrenia $[66,67]$. While a significant reduction in synapsin III protein levels in the prefrontal cortex is recognized as a major cause of dysfunction in schizophrenic patients, molecular studies have identified some polymorphisms in synapsin III which are associated with schizophrenia [68]. The polymorphism $\mathrm{S} 470 \mathrm{~N}$ in the synapsin III gene affects a phosphorylation site, Ser470, which results in the deletion of a mitogen-activated protein kinase site that is phosphorylated during development and more frequent in probands with schizophrenia than in the normal population. These properties suggest a physiological role for Ser470 polymorphism in neuronal plasticity, which is altered in schizophrenia [69]. The possibility of an association of the SNP-196G/A in the promoter region with schizophrenia has also been reported [70].

However, many studies have negated the idea of involvement of synapsin III polymorphisms in schizophrenia. An association and expression study by Chen $e t$ al. did not support a major role for synapsin III in susceptibility to schizophrenia in Irish and Chinese populations [71]. Another study by Ohtsuki et al. in 2000 involved mutation analysis of the synapsin III gene in schizophrenia using the single-strand conformation polymorphism method. Variants in 13 exons and the $5^{\prime}$-flanking region of the synapsin III gene were searched in schizophrenia which led to the identification of three polymorphisms, y631CrG, y271 $\mathrm{TrC}$, and $\mathrm{E} 525 \mathrm{Q}$, and one rare variant, y669C. However, no significant differences in the allelic and genotypic distributions between schizophrenic and control subjects were reported, thus suggesting the absence of an association between the synapsin III gene and schizophrenia [72].
Similarly, three SNPs were identified using a sequencing method, two of which (g.-631C $>$ G and g.-196G $>$ A) were in the $5^{\prime}$ promoter regions, while g. $69 \mathrm{G}>\mathrm{A}$ was at exon 1. But no significant differences in genotype or allele frequency distributions of these SNPs were found between patients and non-psychotic individuals, demonstrating no involvement of the synapsin III gene in the pathogenesis of schizophrenia [73]. Moreover, a linkage- and family-based association study also suggested that chromosome $22 \mathrm{q} 13$ is not likely to contain a schizophrenia susceptibility gene [74]. Interestingly, studies investigating the DNA methylation and mRNA expression of the synapsin III gene also demonstrated no relation of the variation in SYN III methylation to schizophrenia in the population sample or a monozygotic twin pair discordant for schizophrenia or to the mRNA level of SYN IIIa in different human brain regions [75]. Therefore, despite the evidence of a possible involvement of Synapsin III polymorphisms in schizophrenia, most studies have refuted this idea. On the therapeutic front, there is a positive association of the lifetime use of antipsychotic drugs with synapsin IIa expression in schizophrenic patients, which further implies the involvement of synapsin II in the therapeutic mechanisms of these drugs. This could be further exploited to strategize better therapeutic approaches [61].

\section{Bipolar Disorder}

Pursued as a major topic in health research, BD is a significantly prevalent $(1 \%-2 \%)$ psychiatric condition of debilitating nature in the general population. It has been characterized by abnormal episodic shifts in mood ranging from depressive to manic episodes, hindering the carrying out of routine tasks by patients. In BD, the expression of synapsins Ia, IIa, and IIIa is markedly reduced [60].

The involvement of epigenetic regulatory mechanisms in synaptic dysregulation in mood disorders is noteworthy. Interestingly, the synapsin genes are also influenced by these epigenetic factors. Their relationship to enrichment in the H3K4me3 promoter, an epigenetic marker associated with increased transcription, is evident in studies conducted on BD major depression post-mortem brains which show a significant increase in histone modification markers along with a substantial increase in synapsin gene expression [76]. Similarly, a decrease in promoter DNA methylation is also correlated with increased expression of synapsin genes [77].

Moreover, the expression of synapsin is also influenced by alkali metals like lithium. Lithium is a common treatment for BD due to its proven efficacy as a shortterm intervention for manic episodes as well as a prophylactic agent against episode recurrence [78]. 
Abnormalities in synaptic proteins may be a common pathophysiology of BD and schizophrenia, establishing synapsins as a common molecular target for developing better therapeutic strategies for both of these disorders.

\section{Multiple Sclerosis}

Although MS is an autoimmune disease characterized by demyelination in the central nervous system, recent research has revealed that axonal damage characterizes the early stage of the disease. Data based on experimental studies suggest a possible immunogenic role of synapsins, demonstrating an impairment of neurons resulting in the neurological disability of MS [79]. A study by D'Alfonso et al. (1999) linked synapsin III to MS as it located the synapsin III gene to chromosome $22 \mathrm{q} 12-\mathrm{q} 13$ which is in close proximity to one of the potential MS susceptibility regions (22q13.1) [80]. In addition, an inverse association of the g. $-196 \mathrm{G}>\mathrm{A}$ and g. $-631 \mathrm{C}>\mathrm{G}$ polymorphisms at the $5^{\prime}$-promoter region of the synapsin III gene with MS and an association of the g.-631C $>$ G polymorphism with disease onset at a younger age also support the importance of synapsin III as a candidate gene in MS [81].

Also, the significantly decreased expression patterns of synapsin IIa during the early stage of experimental allergic encephalomyelitis strengthen the notion that abnormalities in the release of neurotransmitters and degradation of cytoskeletal elements may contribute to the neuronal deficit [79].

Synapsin-specific $\mathrm{T}$ cells, also known as TH1-like $\mathrm{T}$ cells $[80,82]$, have been associated with the pathogenesis of MS, which has been demonstrated to be mediated by TH1-cytokines [83, 84]. Other studies [85] have also reported the presence of synapsin Ia-specific $\mathrm{T}$ cells along with a similar frequency of myelin basic protein-specific $\mathrm{T}$ cells in the serum of MS patients during different stages of the disease, strongly suggesting a role of synapsins in its development.

\section{Huntington's Disease}

HD is an autosomal dominant neurodegenerative disorder caused by a polyglutamine (polyQ) expansion of $>37$ glutamines in the HD protein huntingtin (htt) and characterized by motor and cognitive deficits [86]. The degeneration in HD occurs preferentially in striatal neurons and extends to other brain regions with the progression of the disease [87]. The role of synapsins in HD is evident from various research findings suggesting that post-translational modifications in synapsins brought about by HD cause abnormalities. An abnormal phosphorylation state of synapsin I is evident in the striatum and the cerebral cortex of R6/2 transgenic mice expressing an HD mutation. These changes are mostly characterized by early overphosphorylation at sites 3-5; they have been shown to occur through a decrease in the expression of the calcineurin regulatory subunit- $\mathrm{B}$, contributing to an imbalance between kinase and phosphatase activities. An early impairment in synapsin phosphorylation-dephosphorylation has been marked as a major contributor to changes in synaptic vesicle trafficking and defective neurotransmission in HD [88]. Also, a study on HD CAG150 knock-in mouse brains revealed a strong binding of mutant htt to the C-terminal region of synapsin-1 to reduce its phosphorylation and thus neurotransmitter release, thereby identifying a critical role of synaptic htt in the neurological symptoms of HD [89].

\section{Others}

In addition to their involvement in the conditions discussed above, synapsins have also been linked to conditions like amyotrophic lateral sclerosis (ALS), autism [90], and hyperalgesia [91]. An immunohistochemical investigation of synaptic proteins has revealed differential expression between the two groups of synaptic proteins in the ALS anterior horn of the spinal cord where synaptic vesicle

Table 2 Mechanisms of synaptic pathology in neurological disorders.

\begin{tabular}{ll}
\hline $\begin{array}{l}\text { Mechanisms associated with synaptic } \\
\text { pathology }\end{array}$ & Neurological disorders \\
\hline $\begin{array}{l}\text { ER stress-associated } \\
\text { neurodegeneration }\end{array}$ & Synapsin I decrease in AD due to ER stress [36] \\
$\begin{array}{l}\text { Protein Interactions } \\
\text { Gene mutations }\end{array}$ & $\begin{array}{l}\text { Synapsin interactions with SORLA in AD [39] } \\
\text { PS-1 mutation in AD [40], Synapsin I and II mutations in epilepsy [50-53], Synapsin II and III mutations } \\
\text { in schizophrenia [63-70] }\end{array}$ \\
$\begin{array}{ll}\text { Altered epigenetic mechanisms } \\
\text { Immunogenicity }\end{array}$ & $\begin{array}{l}\text { Synapsin-specific T cells in MS pathogenesis [82-85] } \\
\text { Post-translational modifications }\end{array}$ \\
\hline
\end{tabular}


proteins including synapsin I are significantly decreased [92]. In addition, proteomic analysis of the spinal cord in a mouse model of ALS showed under-expression of synapsin II [93]. Although these studies provide a promising association of synapsins, further investigations are required to elaborate its possible involvement in ALS.

ASDs, which are complex, multifactorial neurodevelopmental conditions manifested by impaired behavior and social interaction [94], may also be associated with altered synapsin function. A study by Tang et al. in 2015 [90] suggested the possibility of a role of dysfunctional synapsin Ia SUMOylation in neurological disorders like epilepsy and autism. An A548T mutation in synapsin Ia, which is known to be associated with ASD and epilepsy, causes a decrease in synapsin Ia SUMOylation and mirrors the functional defect of non-SUMOylatable synapsin Ia. This study opens avenues for further research on the post-translational modification of synapsins in neurological disorders, creating a paradigm for a better understanding of their role in pathogenesis.

An involvement of synapsin II has also been noted in the synaptic transmission of nociceptive signals in the spinal cord that leads to pain hypersensitivity. A study by Schmidtko et al. in 2005 [91] revealed the expression of synapsin II in terminals and neuronal fibers in the superficial laminae of the dorsal horn (laminae I-II). In addition, a unique role of synapsin II in nociception-evoked glutamate release, hyperalgesia, and c-Fos expression in the dorsal horn, assessed through the effects of its complete and transient deficiency on nociceptive behavior in various models, has been attributed partly to its localization as well as function. Although this indicates that synapsins are involved in pain hypersensitivity, further research in this field is imperative for confirmation of this concept. A brief summary is provided in Table 2 listing the involvement of synapsins in neurological disorders.

\section{Conclusion}

The studies conducted on synapsins reveal that each member of the synapsin family has a unique function at a certain type of presynaptic terminal. Alterations in the activity of synapsins may play crucial roles in several neurological disorders. However, our understanding of the possible roles of synapsins in these disorders can be aided by studies aimed at furthering insights into the molecular pathology of the neurological diseases. An understanding of the functions of different synapsins isoforms will also enable us to answer crucial questions about the contributions of synapsins to different brain functions and neurological disorders.
Compliance with Ethical Standards

Conflict of interest The authors report no conflicts of interest.

\section{References}

1. Song SH, Augustine GJ. Synapsin isoforms and synaptic vesicle trafficking. Mol Cells 2015, 38: 936-940.

2. Fornasiero EF, Bonanomi D, Benfenati F, Valtorta F. The role of synapsins in neuronal development. Cell Mol Life Sci 2010, 67: 1383-1396.

3. Cesca F, Baldelli P, Valtorta F, Benfenati F. The synapsins: key actors of synapse function and plasticity. Prog Neurobiol 2010, 91: 313-348.

4. Masliah E, Terry R. The role of synaptic proteins in the pathogenesis of disorders of the central nervous system. Brain Pathol 1993, 3: 77-85.

5. Goelz SE, Nestler EJ, Chehrazi B, Greengard P. Distribution of protein I in mammalian brain as determined by a detergent-based radioimmunoassay. Proc Natl Acad Sci U S A 1981, 78: 2130-2134.

6. Hilfiker S, Pieribone VA, Czernik AJ, Kao H-T, Augustine GJ, Greengard P. Synapsins as regulators of neurotransmitter release. Philos Trans R Soc Lond B Biol Sci 1999, 354: 269-279.

7. Jovanovic JN, Benfenati F, Siow YL, Sihra TS, Sanghera JS, Pelech SL, et al. Neurotrophins stimulate phosphorylation of synapsin I by MAP kinase and regulate synapsin I-actin interactions. Proc Natl Acad Sci U S A 1996, 93: 3679-3683.

8. Zhang L, Zhao ZX. The impact of synapsins on synaptic plasticity and cognitive behaviors. Neurosci Bull 2006, 22:63-67.

9. Huttner, WB, Schiebler W, Greengard P, De Camilli P. Synapsin I (protein I), a nerve terminal-specific phosphoprotein. III. Its association with synaptic vesicles studied in a highly purified synaptic vesicle preparation. J Cell Biol 1983, 96: 1374-1388.

10. Hosaka M, Hammer RE, Südhof TC. A phospho-switch controls the dynamic association of synapsins with synaptic vesicles. Neuron 1999, 24: 377-387.

11. Sudhof TC, Czernik AJ, Kao HT, Takei K, Johnston PA, Horiuchi A, et al. Synapsins: mosaics of shared and individual domains in a family of synaptic vesicle phosphoproteins. Science 1989, 245: 1474-1480.

12. Kao HT, Porton B, Czernik AJ, Feng J, Yiu G, HÌring M, et al. A third member of the synapsin gene family. Proc Natl Acad Sci U S A 1998, 95: 4667-4672.

13. Hosaka M, Sudhof T. Synapsin III, a novel synapsin with an unusual regulation by $\mathrm{Ca} 2+$. J Biol Chem 1998, 273: 13371-13374.

14. Ferreira A, Rapoport M. The synapsins, beyond the regulation of neurotransmitter release. Cell Mol Life Sci 2002, 59: 589-595.

15. Coleman WL, Bykhovskaia M. Synapsin I accelerates the kinetics of neurotransmitter release in mouse motor terminals. Synapse 2009, 63: 531-533.

16. Hendricks BK, Shi R. Mechanisms of neuronal membrane sealing following mechanical trauma. Neurosci Bull 2014, 30: 627-44.

17. Ferreira A, Chin LS, Li L, Lanier LM, Kosik KS, Greengard P. Distinct roles of synapsin I and synapsin II during neuronal development. Mol Med 1998, 4: 22-28.

18. Terada S, Tsujimoto T, Takei Y, Takahashi T, Hirokawa N. Impairment of inhibitory synaptic transmission in mice lacking synapsin I. J Cell Biol 1999, 145: 1039-1048.

19. Li L, Chin LS, Shupliakov O, Brodin L, Sihra TS, Hvalby O, et al. Impairment of synaptic vesicle clustering and of synaptic transmission, and increased seizure propensity, in synapsin I-deficient mice. Proc Natl Acad Sci 1995, 92: 9235-9239. 
20. Ferreira A, Kosik KS, Greengard P, Han HQ. Aberrant neurites and synaptic vesicle protein deficiency in synapsin II-depleted neurons. Science 1994, 264: 977-979.

21. Ferreira A, Han HQ, Greengard P, Kosik KS. Suppression of synapsin II inhibits the formation and maintenance of synapses in hippocampal culture. Proc Natl Acad Sci U S A 1995, 92: 9225-9229.

22. Coleman WL, Bill CA, Simsek-Duran F, Lonart G, Samigullin D, Bykhovskaia M. Synapsin II and calcium regulate vesicle docking and the cross-talk between vesicle pools at the mouse motor terminals. J Physiol 2008, 586: 4649-4673.

23. Gitler D, Cheng Q, Greengard P, Augustine GJ. Synapsin IIa controls the reserve pool of glutamatergic synaptic vesicles. J Neurosci 2008, 28: 10835-10843.

24. Han HQ, Nichols RA, Rubin MR, Bahler M, Greengard P. Induction of formation of presynaptic terminals in neuroblastoma cells by synapsin IIb. Nature 1991, 349: 697-700.

25. Ferreira A, Kao HT, Feng J, Rapoport M, Greengard P. Synapsin III: developmental expression, subcellular localization and role in axon formation. J Neurosci 2000, 20: 3736-3744.

26. Kao HT, Li P, Chao HM, Janoschka S, Pham K, Feng J, et al. Early involvement of Synapsin III in neural progenitor cell development in the adult hippocampus. J Comp Neurol 2008, 507: $1860-1870$.

27. Feng J, Chi P, Blanpied TA, Xu YM, Magarinos AM, Ferreira A, et al. Regulation of neurotransmitter release by synapsin III. J Neurosci 2002, 22: 4372-4380.

28. Anand R, Gill KD, Mahdi AA. Therapeutics of Alzheimer's disease: past, present and future. Neuropharmacology 2014, 76: 27-50.

29. Norfray JF, Provenzale JM. Alzheimer's disease: neuropathologic findings and recent advances in imaging. AJR Am J Roentgenol 2004, 182: 3-13.

30. Bozoki AC, Korolev IO, Davis NC, Hoisington LA, Berger KL. Disruption of limbic white matter pathways in mild cognitive impairment and Alzheimer's disease: a DTI/FDG-PET study. Hum Brain Mapp 2012, 33: 1792-1802.

31. Holtzman DM, Morris JC, Goate AM. Alzheimer's disease: the challenge of the second century. Sci Transl Med 2011, 3: 77sr1.

32. Terry RD, Masliah E, Salmon DP, Butters N, DeTeresa R, Hill R, et al. Physical basis of cognitive alterations in Alzheimer's disease: synapse loss is the major correlate of cognitive impairment. Ann Neurol 1991, 30: 572-580.

33. Arriagada PV, Growdon JH, Hedley-Whyte ET, Hyman BT. Neurofibrillary tangles but not senile plaques parallel duration and severity of Alzheimer's disease. Neurology 1992, 42: 631-639.

34. Song Q, Xiang-You H, Hao X, Jiang-Ning Z. Regional alteration of synapsin I in the hippocampal formation of Alzheimer's disease patients. Acta Neuropathol 2004, 107: 209-215.

35. Jovanovic JN, Czernik AJ, Fienberg AA, Greengard P, Sihra TS. Synapsins as mediators of BDNF-enhanced neurotransmitter release. Nat Neurosci 2000, 3: 323-329.

36. Lin L, Yang SS, Chu J, Wang L, Ning LN, Zhang T, Jiang Q, Tian Q, Wang JZ. Region-specific expression of tau, amyloid- $\beta$ protein precursor, and synaptic proteins at physiological condition or under endoplasmic reticulum stress in rats. J Alzheimer's Dis 2014, 41: 1149-1163.

37. Scheff SW, Price DA, Ansari MA, Roberts KN, Schmitt FA, Ikonomovic MD, et al. Synaptic change in the posterior cingulate gyrus in the progression of Alzheimer's disease. J Alzheimer's Dis 2015, 43:1073-1090.

38. Scheff SW, Price DA. Alzheimer's disease-related synapse loss in the cingulate cortex. J Alzheimer's Dis 2001; 3: 495-505.
39. Hartl D, Nebrich G, Klein O, Stephanowitz H, Krause E, Rohe M. SORLA regulates calpain-dependent degradation of synapsin. Alzheimers Dement 2016, 12: 952-963.

40. Haleem K, Lippa CF, Smith TW, Kowa H, Wu J, Iwatsubo T. Presenilin-1 C410Y Alzheimer disease plaques contain synaptic proteins. Am J Alzheimers Dis Other Dement 2007, 22: 137-144.

41. Li S, Yan Y, Jiao Y, Gao Z, Xia Y, Kong L, et al. Neuroprotective effect of osthole on neuron synapses in an Alzheimer's disease cell model via upregulation of microRNA-9. J Mol Neurosci 2016, 60: 71-81.

42. Adler BL, Yarchoan M, Hwang HM, Louneva N, Blair JA, Palm R, Smith MA, Lee HG, Arnold SE, Casadesus G. Neuroprotective effects of the amylin analogue pramlintide on Alzheimer's disease pathogenesis and cognition. Neurobiol Aging 2014, 35: 793-801.

43. Dawson GR, Seabrook GR, Zheng H, Smith DW, Graham S, O'Dowd G, et al. Age-related cognitive deficits, impaired longterm potentiation and reduction in synaptic marker density in mice lacking the beta-amyloid precursor protein. Neurosci 1999, 90: 1-13.

44. Ho L, Guo Y, Spielman L, Petrescu O, Haroutunian V, Purohit D, et al. Altered expression of a-type but not b-type synapsin isoform in the brain of patients at high risk for Alzheimer's disease assessed by DNA microarray technique. Neurosci Lett 2001, 298: 191-194.

45. Suemaru S, Sato K, Morimoto K, Yamada N, Sato T, Kuroda S. Increment of synapsin I immunoreactivity in the hippocampus of the rat kindling model of epilepsy. Neuroreport 2000, 11: 1319-1322.

46. Carl ES. Epilepsy: a review of selected clinical syndromes and advances in basic science. J Cereb Blood Flow Metab 2006, 26: 983-1004.

47. Henry TR, Roman DD. Presurgical epilepsy localiztion with interictal cerebral dysfunction. Epilepsy Behav 2011, 20: 194-208.

48. Fisher RS, van Emde Boas W, Blume W, Elger C, Genton P, Lee $\mathrm{P}$, et al. Epileptic seizures and epilepsy: definitions proposed by the International League Against Epilepsy (ILAE) and the International Bureau for Epilepsy (IBE). Epilepsia 2005, 46: 470-472.

49. Etholm L, Heggelund P. Seizure elements and seizure element transitions during tonic-clonic seizure activity in the synapsin I/II double knockout mouse: a neuroethological description. Epilepsy Behav 2009, 14: 582-590.

50. Fassio A, Patry Le, Congia S, Onofri F, Piton A, Gauthier J, et al. SYN1 loss-of-function mutations in autism and partial epilepsy cause impaired synaptic function. Hum Mol Genet 2011, 20: 2297-2307.

51. Garcia CC, Blair HJ, Seager M, Coulthard A, Tennant S. Identification of a mutation in synapsin I, a synaptic vesicle protein, in a family with epilepsy. J Med Genet 2004, 41: $183-186$.

52. Lignani G, Raimondi A, Ferrea E, Rocchi A, Paonessa F, Cesca $\mathrm{F}$, et al. Epileptogenic Q555X SYN1 mutant triggers imbalances in release dynamics and short-term plasticity. Hum Mol Genet 2013, 22: 2186-2199.

53. Prasad DK, Shaheen U, Satyanarayana U, Prabha TS, Jyothy A, Munshi A. Association of GABRA6 1519 T > C (rs3219151) and Synapsin II (rs37733634) gene polymorphisms with the development of idiopathic generalized epilepsy. Epilepsy Res 2014, 108: 1267-1273.

54. Harrison PJ. Schizophrenia susceptibility genes and neurodevelopment. Biol Psychiatry 2007, 61: 1119-1120.

55. Li B, Cui LB, Xi YB, Friston KJ, Guo F, Wang HN, Zhang LC, Bai YH, Tan QR, Yin H, Lu H. Abnormal effective connectivity 
in the brain is involved in auditory verbal hallucinations in schizophrenia. Neurosci Bull 2017, 33: 281-291.

56. Calabresi P, Centonze D, Gubellini P, Marfia GA, Pisani A, Sancesario G, et al. Synaptic transmission in the striatum: from plasticity to neurodegeneration. Prog Neurobiol 2000, 61: 231-265.

57. Harrison PJ. The neuropathology of schizophrenia. A critical review of the data and their interpretation. Brain 1999, 122: 593-624.

58. Dyck BA, Beyaert MG, Ferro MA, Mishra RK. Medial prefrontal cortical synapsin II knock-down induces behavioral abnormalities in the rat: examining synapsin II in the pathophysiology of schizophrenia. Schizophr Res 2011, 130: 250-259.

59. Mirnics K, Middleton FA, Marquez A, Lewis DA, Levitt P. Molecular characterization of schizophrenia viewed by microarray analysis of gene expression in prefrontal cortex. Neuron 2000, 28: 53-67.

60. Vawter M, Thatcher L, Usen N, Hyde T, Kleinman J, Freed W. Reduction of synapsin in the hippocampus of patients with bipolar disorder and schizophrenia. Mol Psychiatry 2002, 7: 571-578.

61. Tan ML, Dyck BA, Gabriele J, Daya RP, Thomas N, Sookram C, et al. Synapsin II gene expression in the dorsolateral prefrontal cortex of brain specimens from patients with schizophrenia and bipolar disorder: effect of lifetime intake of antipsychotic drugs. Pharmacogenomics J 2014, 14: 63-69.

62. Porton B, Wetsel WC. Reduction of synapsin III in the prefrontal cortex of individuals with schizophrenia. Schizophr Res 2011, 94 : 366-370.

63. Saviouk V, Moreau MP, Tereshchenko IV, Brzustowicz LM. Association of synapsin 2 with schizophrenia in families of Northern European ancestry. Schizophr Res 2007, 96: 100-111.

64. Chen Q, He G, Wang XY, Chen QY, Liu XM, Gu ZZ, et al. Positive association between synapsin II and schizophrenia. Biol Psychiatry 2004, 56: 177-181.

65. Chen Q, He G, Qin W, Chen QY, Zhao XZ, Duan SW, et al. Family-based association study of synapsin II and schizophrenia. Am J Hum Genet 2004, 75: 873-877.

66. Gill M, Vallada H, Collier D, Sham P. A combined analysis of D22S278 marker alleles in affected sib-pairs: Support for a susceptibility locus for schizophrenia at chromosome 22q12. Am J Med Genet 1996, 67: 40-45.

67. Vallada H, Curtis D, Sham P, Kunugi H, Zhao JH, Murray R, et al. A transmission disequilibrium and linkage analysis of D22S278 marker alleles in 574 families: further support for a susceptibility locus for schizophrenia at 22q12. Schizophr Res 1998, 32: 115-121.

68. Porton B, Wetsel WC, Kao HT. Synapsin III: role in neuronal plasticity and disease. Semin Cell Dev Biol 2007, 22: 416-424.

69. Porton B, Ferreira A, DeLisi LE, Kao HT. A rare polymorphism affects a mitogen-activated protein kinase site in synapsin III: possible relationship to schizophrenia. Biol Psychiatry 2004, 55: $118-125$.

70. Lachman HM, Stopkova P, Papolos DF, Pedrosa E, Margolis B, Aghalar MR, et al. Analysis of synapsin III-196 promoter mutation in schizophrenia and bipolar disorder. Neuropsychobiol 2006, 53: 57-62.

71. Chen Q, Che R, Wang X, O'Neill FA, Walsh D, Tang W, et al. Association and expression study of synapsin III and schizophrenia. Neurosci Lett 2009, 465: 248-251.

72. Ohtsuki T, Ichiki R, Toru M, Arinami T. Mutational analysis of the synapsin III gene on chromosome 22q12-q13 in schizophrenia. Psychiatry Res 2000, 94: 1-7.

73. Tsai MT, Hung CC, Tsai CY, Liu MY, Su YC, Chen YH, et al. Mutation analysis of synapsin III gene in schizophrenia. Am J Med Genet 2002, 114: 79-83.
74. Stöber G, Meyer J, Nanda I, Wienker TF, Saar K, Knapp M, et al. Linkage and family-based association study of schizophrenia and the synapsin III locus that maps to chromosome 22q13. Am J Med Genet 2000, 96: 392-397.

75. Murphy BC, O'Reilly RL, Singh SM. DNA methylation and mRNA expression of SYN III, a candidate gene for schizophrenia. BMC Med Genet 2008, 9: 115.

76. Cruceanu C, Alda M, Nagy C, Freemantle E, Rouleau GA, Turecki G. H3K4 tri-methylation in synapsin genes leads to different expression patterns in bipolar disorder and major depression. Int J Neuropsychopharmacol 2013, 16: 289-299.

77. Cruceanu C, Kutsarova E, Chen ES, Checknita DR, Nagy C, Lopez JP, et al. DNA hypomethylation of Synapsin II CpG islands associates with increased gene expression in bipolar disorder and major depression. BMC Psychiatry 2016, 16: 286.

78. Cruceanu C, Alda M, Grof P, Rouleau GA, Turecki G. Synapsin II is involved in the molecular pathway of lithium treatment in bipolar disorder. PLoS One 2012, 7: e32680.

79. Nicot A, Ratnakar PV, Ron Y, Chen CC, Elkabes S. Regulation of gene expression in experimental autoimmune encephalomyelitis indicates early neuronal dysfunction. Brain 2003, 126: $398-412$.

80. D'Alfonso S, Nistico L, Zavattari P, Marrosu MG, Murru R, Lai $\mathrm{M}$, et al. Linkage analysis of multiple sclerosis with candidate region markers in Sardinian and Continental Italian families. Eur J Hum Genet 1999, 7: 177-185.

81. Liguori M1, Cittadella R, Manna I, Valentino P, La Russa A, Serra $\mathrm{P}$, et al. Association between Synapsin III gene promoter polymorphisms and multiple sclerosis. J Neurol 2004, 251: 165-170.

82. Pette M, Pette DF, Muraro PA, Farnon E, Martin R, McFarland $\mathrm{HF}$. Interferon-beta interferes with the proliferation but not with the cytokine secretion of myelin basic protein-specific, T-helper type 1 lymphocytes. Neurology 1997, 49: 385-392.

83. Weber F, Polak T, Gunther A, Kubuschok B, Janovskaja J, Bitsch $A$, et al. Synergistic immunomodulatory effects of interferon- $\beta 1 \mathrm{~b}$ and the phosphodiesterase inhibitor pentoxifylline in patients with relapsing remitting multiple sclerosis. Ann Neurol 1998, 44: 27-34.

84. Rieckmann P, Albrecht M, Kitze B, Weber T, Tumani H, Broocks A, et al. Tumor necrosis factor-alpha messenger RNA expression in patients with relapsing-remitting multiple sclerosis is associated with disease activity. Ann Neurol 1995, 37: 82-88.

85. Polak T, Schlaf G, Scholl U, Krome-Cesar C, Mader M, Felgenhauer $\mathrm{K}$, et al. Characterization of the human $\mathrm{T}$ cell response against the neuronal protein synapsin in patients with multiple sclerosis. J Neuroimmunol 2001, 115: 176-181.

86. Orr HT, Zoghbi HY. Trinucleotide repeat disorders. Annu Rev Neurosci 2007, 30:575-621.

87. Vonsattel JP, DiFiglia M. Huntington disease. J Neuropathol Exp Neurol 1998, 57:369-384.

88. Liévens JC, Woodman B, Mahal A, Bates GP. Abnormal phosphorylation of synapsin I predicts a neuronal transmission impairment in the R6/2 Huntington's disease transgenic mice. Mol Cell Neurosci 2002, 20: 638-648.

89. Xu Q, Huang S, Song M, Wang CE, Yan S, Liu X, et al. Synaptic mutant huntingtin inhibits synapsin-1 phosphorylation and causes neurological symptoms. J Cell Biol 2013, 202: 1123-1138.

90. Tang LT, Craig TJ, Henley JM. SUMOylation of synapsin Ia maintains synaptic vesicle availability and is reduced in an autism mutation. Nat Commun 2015, 6: 7728.

91. Schmidtko A, Del Turco D, Costea O, Ehnerta C, Niederbergera E. Essential role of the synaptic vesicle protein synapsin II in formalin-induced hyperalgesia and glutamate release in the spinal cord. Pain 2005, 115: 171-181. 
92. Ikemoto A, Nakamura S, Akiguchi I, Hirano A. Differential expression between synaptic vesicle proteins and presynaptic plasma membrane proteins in the anterior horn of amyotrophic lateral sclerosis. Acta Neuropathol 2002, 103: 179-187.

93. Lukas TJ, Luo WW, Mao H, Cole N, Siddique T. Informaticsassisted protein profiling in a transgenic mouse model of amyotrophic lateral sclerosis. Mol Cell Proteomics 2006, 5: $1233-1244$.

94. Masi A, DeMayo MM, Glozier N, Guastella AJ. An overview of autism spectrum disorder, heterogeneity and treatment options. Neurosci Bull 2017, 33: 183. 